\title{
Implementasi bimbingan vokasional melalui keterampilan otomotif roda dua untuk pecandu NAPZA usia produktif sebagai bekal keterampilan pasca rehabilitasi
}

\section{Rendi Pidura ${ }^{1}$}

\author{
${ }^{1}$ Mahasiswa Prodi Bimbingan \\ dan Konseling Islam, IAIN \\ Syaikh Abdurrahman Siddik \\ Bangka Belitung
}

\section{Korespondensi}

pidurarendy@gmail.com

\begin{abstract}
This research is motivated because there are still relapses or relapses of productive age drug addicts after entering the post-rehabilitation stage and this research is also a provision of skills for drug addicts and as a place to shift focus and channel their emotional condition after completing rehabilitation. Based on this, this research will discuss and find out how to implement vocational guidance through wheeled automotive skills. This research is a field research which is analyzed using descriptive qualitative method. Data collection techniques were carried out through interviews, observations, and documentation related to what the researchers did. The results of this study indicate that there are 3 stages of vocational guidance through two-wheeled automotive skills, namely the initial stage: assessment, building relationships and agreeing contracts. The core stage is divided into 5 stages of work, namely: knowing what the client wants in what field, looking for cooperation links, offering training and making contracts, holding debriefing, accompanying and directing clients through training. Core stage: follow-up.

\section{KEYWORDS}

Vocational guidance, Two-wheeled automotive skills, Drug addicts.
\end{abstract}




\begin{abstract}
Abstrak
Penelitian ini dilatarbelakangi karena masih adanya kekambuhan atau relapse pecandu NAPZA usia produktif setelah memasuki tahap pasca rehabilitas dan penelitian ini juga sebagai bekal keterampilan bagi pecandu NAPZA dan sebagai tempat peralihan fokus dan tempat penyalur kondisi emosional mereka setelah selesai menjalani rehabilitas. Berdasarkan hal tersebut, penelitian ini akan membahas dan mengetahui bagaimana implementasi bimbingan vokasional melalui keterampilan otomotif roda. Penelitian ini adalah penelitian lapangan (field reseach) yang dianalisis dengan menggunakan metode kualitatif deskriptif. Teknik pengumpulan data dilakukan melalui cara, wawancara, observasi, dan dokumetasi terkait dengan yang peneliti lakukan. Hasil penelitian ini menunjukkan bahwa Bimbingan vokasional melalui keterampilan otomotif roda dua terdapat 3 tahapan, yakni tahap awal: assessment, membangun hubungan dan menyepakati kontrak. Tahap inti terbagi menjadi 5 tahapan kerja yakni: mengetahui kemauan klien dibidang apa, mencari link kerja sama, menawarkan pelatihan dan membuat kontrak, mengadakan pembekalan, mendampingi dan mengarahkan klien menjalani pelatihan. Tahap inti: follow up.
\end{abstract}

\title{
KATA KUNCI:
}

Bimbingan vokasional, keterampilan otomotif roda dua, pencandu NAPZA 


\section{1 | Pendahuluan}

Narkotika, Psikotropika, dan Zat Adaktif (NAPZA) merupakan barangbarang haram dan terlarang yang seharusnya tidak boleh di konsumsi oleh semua kalangan dan lapisan masyarakat. Pernyataan ini akan tetapi hanya semacam sebuah peraturan yang sama sekali tidak di hiraukan oleh para penggunanya. Masih banyak sekali lapisan masyarakat yang menyalahgunakan NAPZA, bahkan ada yang ketergantungan dengan barang haram ini, paling disesalkan banyak generasi muda usia produktif yang menyalahgunakan NAPZA. Badan Narkotika Nasional (BNN) menyebutkan $80 \%$ pengguna NAPZA merupakan generasi usia produktif kisaran umur 1539 tahun [1].

Dalam perspektif Islam, permasalahan penyalahgunaan NAPZA merupakan masalah ijtihad karena tidak disebutkan secara langsung dalam Alqur'an dan sunnah. Pada zaman Rasulullah yang ada pada waktu itu hanya khamar sedangkan narkoba tidak dikenal pada masa itu. Sanksi pidana bagi pelaku penyalahgunaan menjadi wewenang hakim untuk menjatuhkan hukuman ta'zir (hukum yang dijatuhkan atas dasar kebijaksanaan hakim karena tidak terdapat dalam Al-Qur'an dan Hadist). akibat dari pelanggaran terhadap larangan agama [2].

Angka penyalahgunaan NAPZA pada tahun 2018 mencapai angka 2,29 juta orang rentan usia 15-35 tahun. Pada tahun 2019 mengalami peningkatan lagi hingga menembus angka 3,6 juta orang, rentan usia pada tahun ini 15-65 tahun. Heru Winarko juga menuturkan bahwa sejauh ini jenis Narkoba yang paling banyak digunakan di Indonesia adalah ganja, penggunanya mencapai 63 persen [3].

Berdasarkan data di atas dapat di lihat bahwa di Indonesia sendiri angka pengguna NAPZA setiap tahunnya terus mengalami peningkatan yang memprihatinkan. Permasalahan ini menjadi masalah serius yang di hadapi oleh Indonesia pada saat ini, karena hampir semua kalangan yang menjadi korban dari NAPZA.

Permasalahan penyalahgunaan NAPZA di usia produktif disebabkan oleh keadaan emosional seseorang yang sangat labil dan ada rasa ingin mencoba sesuatu yang baru. Pada umumnya 
pecandu NAPZA memiliki beberapa alasan menggunakan barang haram ini misalnya sebagai tempat pelarian untuk menenangkan pikiran, agar terlihat keren, untuk menunjukkan perlawanan, agar terlihat dewasa, bahkan ada awalnya hanya ingin mencoba sampai akhirnya ketagihan. Adanya rasa ingin mencoba hal baru tadi, seseorang yang sedang berada di usia produktif sangat mudah sekali tergiur dengan tawarantawaran yang datang dari teman yang usianya lebih tua dari mereka atau orang yang lebih dulu mengkonsumsi barang haram ini.

Rata- rata pengguna NAPZA usia produktif di Indonesia adalah orang yang putus sekolah dan tidak memiliki pekerjaan tetap. Naka dari itu penanganan dari permasalahan ini juga harus tepat bukan hanya direhabilitas tetapi juga harus diberikan sebuah keterampilan yang bisa mereka jadikan sebagai bekal untuk mereka di masa depan.

\section{Metode}

Untuk metode yang digunakan pada punulisan ini seperti penjelasan pada bagian abstrak, metode yang digunakan adalah metode kualitatif deskriptif, dengan melihat jurnal, buku, artikel, isu-isu dan berita yang berkaitan dengan opini permasalahan diatas.

\section{3 | Hasil dan Pembahasan}

Salah satu upaya yang bisa dilakukan untuk menangani korban penyalahgunaan NAPZA dengan melakukan rehabilitas. Rehabilitas merupakan cara pemulihan pengguna narkoba dengan jangka waktu panjang maupun pendek, ini bertujuan untuk mengubah perilaku dan menormalkan kembali fungsi-fungsi fisik pengguna tersebut. karena narkoba menimbulkan berbagai gangguan pada fisik dan kejiwaan penggunanya dan juga bisa memberikan dampak sosial bagi korbannya [4].

Melakukan rehabilitas terhadap pengguna dan pecandu NAPZA sangat diperlukan. Dalam pelaksanaan rehabilitas, pecandu NAPZA usia produktif juga akan di berikan program bimbingan vokasional. Artinya selain di rehab para pecandu NAPZA juga akan diberikan dan diajarkan keterampilan khusus. Program layanan keterampilan vokasional ini di terapkan untuk lebih 
Qunselle

Reviewed : 29-Oct-2021 | Accepted : 08-Dec-2021 | Published : 31-Dec-2021

e-ISSN 2798-4230

DOI: $10.32923 /$ couns.v1i2.1907

$\mathrm{p}-$ ISSN $x \mathrm{xxx}-\mathrm{x} x \mathrm{xx}$

Vol. 1, No. 2, Dec (2021)

meningkatkan dan menunjang

humanistik, yang di dalamnya

kemampuan serta keterampilan khusus

untuk pecandu NAPZA.

Bimbingan vokasional merupakan

salah satu program atau layanan yang terdapat di dalam pelaksanaan

rehabilitas. Program keterampilan

vokasional merupakan layanan untuk menggali potensi dan mengembangkan potensi tersebut. program ini memberikan keterampilan yang praktis, terpakai sesuai dengan kebutuhan pasar kerja [5].

Menurut Anwar program keterampilan vokasional ini adalah program untuk mengembangkan sebuah potensi atau keterampilan, ia juga menuturkan bahwa dengan memiliki keterampilan khusus seseorang dapat memiliki bekal untuk mencapai taraf hidup yang lebih baik [6]. Hal ini sangat berkaitan erat dengan tujuan dari bimbingan itu sendiri, yang di mana salah satu tujuan dari bimbingan adalah untuk mengembangkan seluruh potensi yang di miliki oleh seseorang, pendapat ini dikemukakan oleh Akhmad Sudrajat. Hal ini juga di dukung oleh sebuah pendekatan atau teori yang dikemukakan oleh Abraham Maslow yakni pendekatan 
Program keterampilan vokasional merupakan upaya pencegahan dari konselor kepada pecandu NAPZA yang dilakukan dengan cara yang terkordinir secara berkesinambungan dengan mengadakan pelayanan-pelayanan latihan kerja (vocational training), hal ini diterapkan guna memastikan dan mengharapkan para pecandu NAPZA setelah menjalani proses rehabilitasi dan kembali ke lingkungan masyarakat dapat memperoleh pekerjaan yang layak [7]. Dalam proses keterampilan vokasional, bekal bimbingannya diharapkan mampu mengembangkan kemampuannya dan meningkatkan mental bagi para pecandu NAPZA, sehingga mereka mampu menghasilkan sesuatu hal sesuai dengan tingkat kemampuan dan keterampilan yang mereka miliki.

Dalam hal ini penulis lebih memfokuskan pada keterampilan vokasional otomatif roda dua. Otomotif roda dua sendiri adalah sebuah ilmu yang memperlajari tentang dubia mesin terkhusus kemdaraan roda dua. Otomotif roda dua juga memiliki disiplin ilmu yang sangat spesifik membahas tentang berbagai komponen dari sistem-sitem yang ada pada kendaraan roda dua [8].
Tujuan keterampilan ini secara umum sangat mengacu pada UndangUndang Sistem Pendidikan Nasional (UU SPN) pasal 3 tentang tujuan pendidikan nasional bahwa pendidikan harus mempersiapkan seseorang atau peserta didik untuk siap bekerja dalam bidang tertentu. Secara khusus tujuan keterampilan otomotif roda dua ini untuk membekali seseorang dengan keterampilan, sikap dan pengetahuan agar seseorang dapat kompeten dalam bidang tersebut, terutama dalam hal otomotif roda dua [9]. Dengan memberikan keterampilan otomotif roda dua bagi pecandu NAPZA diharapkan mereka dapat mandiri secara ekonomi, dan bisa membangun usaha sendiri, sekaligus menanamkan sikap dan jiwa bisnis serta kewirausahaan sebagai bekal untuk menghadapi dunia kerja dengan keterampilan tersebut.

\section{4 | Pembahasan (Proses}

Bimbingan Vokasional Melalui Keterampilan Otomotif Roda Dua Untuk Pecandu NAPZA Usia Produktif)

Akhmad Sudrajat berpendapat bahwa bimbingan vokasional harus diberikan kepada remaja termasuk yang 
berada pada usia produktif agar dapat membantu mereka untuk memperoleh pekerjaan dengan keterampilan yang telah diajarkan. Secara umum Akmad Sudrajat mengatakan proses bimbingan dan konseling terbagi menjadi tiga tahapan yakni tahap awal, tahap inti dan tahap akhir yang bisa dijadikan landasan dalam pemberian bimbingan vokasional. Berikut proses dan tahapan dalam pemberian bimbingan vokasional:

\subsection{Tahap Awal}

Membuat panafsiran atau penjajagan dari permasalahan klien dengan mencari tahu data diri klien atau bisa dibilang dengan assessment.

Membangun hubungan yang baik dengan klien. Menetapkan kontrak bimbingan.

\section{2 | Tahap Inti}

Tahap inti merupakan tahap kerja atau tahap pemecahan masalah dari klien dengan menggunakan berbagai teknik atau cara yang bisa dikembangkan oleh konselor. Pada intinya tahap ini merupakan tahap pelatihan atau treatment yang diberikan konselor kepada konselinya.
Vol. 1, No. 2, Dec (2021)

Proses dan tahapan dari pelaksanaan bimbingan vokasional terkhusus untuk pecandu NAPZA atau orang yang menjalani rehabilitas sejatinya diberikan setelah konseli selesai menjalani rehabilitas dan masuk ke tahap pasca rehabilitas ini bertujuan agar komitmen konseli saat menjalani bimbingan vokasional bisa maksimal. Akhmad sudrajat berpendapat ada beberapa hal yang harus diterapkan dalam pemberian bimbingan vokasional yang akan penulis jabarkan sebagai berikut:

Konselor harus menentukan tempat dan pelatihan yang akan diberikan. Tes bakat dan minat agar mengetahui potensi konseling.

Konselor harus menentukan minat, bakat serta kemauan yang ada pada konseli untuk menentukan dan memberikan keterampilan apa yang cocok diberikan untuk konseli tersebut.

Menyepakati kontrak, konselor dan konseli harus menyepakati berbagai perjanjian diantaranya kontrak waktu, tugas dan kerja sama serta komitmen dalam pelaksanaan pelatihan. Memberikan pembekelan mengenai teori vokasional yang akan diberikan. 
Pemberian keterampilan, Langkah ini merupakan usaha untuk melaksanakan bantuan sesuai dengan ketentuan yang telah disepakati pada tahap penjajagan, penafsiran dan eksplorasi.

\section{3 | Tahap Akhir}

Konselor dan konseli membuat kesimpulan mengenai hasil dari proses bimbingan yang telah dijalani dan menyusun rencana tindakan yang akan dilakukan setelah proses ini.

\subsubsection{Follow Up [10]}

Kompetensi Dasar Yang Diberikan Dalam Keterampilan Otomotif Roda Dua. Memahami tentang prinsip kerja kendaraan roda dua. Diajarkan untuk memahami berbagai alat beserta fungsinya dalam kendaraan roda dua.

Diajarkan untuk menggunakan alat-alat mekanik yang berfungsi untuk memperbaiki kendaraan roda dua.

Diajarkan untuk memahami berbagai kerusakan dan permasalahan yang ada pada kendaraan roda dua agar bisa mendiagnosis penyebab dari kerusakan tersebut.

Memahami dan mampu merawat alat kerja dan lingkungan kerjanya.
Diberikan pemahaman tentang bagaimana cara melayani konsumen dengan baik [11].

Dalam penanganan orang yang mengalami kecanduan dengan NAPZA perlu penanganan yang tepat. Bimbingan vokasional melalui keterampilan otomotif roda dua ini sangat cocok sekali diterapkan setelah pasca rehabilitas. Karena sebagai bekal bagi mereka dimasa depan nanti yang bisa mereka jadikan bekal untuk membuka usaha.

\section{5 | Penutup}

Berdasarkan penjelasan diatas dapat disimpulkan bahwa penerapan bimbingan vokasional melalui keterampilan otomotif roda dua sebagai bekal keterampilan pasca rehabilitas sangat tepat sekali diterapkan. Karena jika hanya menjalani proses pemulihan saja menurut penulis itu kurang bagi pecandu yang berada di usia produktif. Orang yang berada di usia produktif membutuhkan pekerjaan yang tetap dan tempat focus agar mereka bisa menata masa depan yang lebih cerah dan terhindar dari barang haram ini pada intinta bekal keterampilannya itu bisa mereka jadikan tempat peralihan fokus. 


\section{Daftar Pustaka}

[1]. Mei Wulandari C, Ajeng Retnowati D, Judi Handojo K. Faktor-Faktor Yang Mempengaruhi Penyalahgunaan Napza Pada Masyarakat Di Kabupaten Jember. Jurnal Farmasi Komunitas. 2015;2(1).

[2]. Ahmad Syafii, Penyalahgunaan NAPZA dalam perspektif Hukum Positif dan Hukum Islam, Bandung: Hunafa, 2015, p. 220.

[3]. Liputan6.com, https://m.liputan6.com/news/read/4127 338/kepala-bnn-pengguna-narkobapada-2019-tembus-36-juta-orang, Diakses pada tanggal: 18 November 2020.

[4]. Anisa Dachlan T, Jordi A, Megawati M, Berutu J. REHABILITASI SEBAGAI UPAYA PENANGGULANGAN PENYALAHGUNAAN NARKOTIKA. Scripta: Jurnal Ilmiah Mahasiswa. 2019;1(1).

[5]. Anwar, Pendidikan Kecakapan Hidup (life Skill Education), Bandung: Alfabeta, 2004, p. 20.

[6]. Anwar, Pendidikan Kecakapan Hidup (life Skill Education), Bandung: Alfabeta, 2004, p. 38.

[7]. Hermin Nugraheni,Tri Wiyatini IW. Kesehatan Masyarakat dalam Determinan Sosial Budaya. CV. Budi Utama. 2018.

[8]. Administrator, https://www.galeri.id/otomotif/penge rtian-otomotif-ruang-lingkup-cabangilmu-teknik-dan-sistemnya, diakses pada tanggal 18 Februari 2021

[9]. Anggit Setiawan. Manajemen Pelatihan Otomotif Roda Dua (Studi
Kasus Pada Balai Rehabilitasi Sosial Wira Adhi Karya di Unggran), [Skripsi]. Semarang Jurusan Pendidikan Nonformal, Universistas Negeri Semarang, 2018.

[10]. Maryatul Kibhtiyah, Bimbingan dan Konseling Karir, Semarang: Karya Abadi Jaya, 2015 p. 14.

[11]. Hidayat D. Pelatihan Keterampilan Otomotif untuk Meningkatkan Kesempatan Kerja di Balai Latihan Kerja Kabupaten Karawang. Journal of Nonformal Education and Community Empowerment. 2017;1(1). 